\title{
ArcheoSciences
}

Revue d'archéométrie

\section{Gold foil covering of the handle of an iron knife from burial 2 of the Hunnic Period cemetery at Mukhino, in the Upper Don area}

L'ornement en or du manche d'un poignard en fer de la tombe 2 de la période des Huns de la nécropole de Moukhino, dans le Haut Don

Saprykina Irina, Yurii A. Teterin and Robert Mitoyan

(2) OpenEdition

Journals

Electronic version

URL: https://journals.openedition.org/archeosciences/2282

DOI: 10.4000/archeosciences.2282

ISBN: 978-2-7535-1598-7

ISSN: 2104-3728

Publisher

Presses universitaires de Rennes

Printed version

Date of publication: 31 December 2009

Number of pages: $255-257$

ISBN: 978-2-7535-1181-1

ISSN: 1960-1360

Electronic reference

Saprykina Irina, Yurii A. Teterin and Robert Mitoyan, "Gold foil covering of the handle of an iron knife from burial 2 of the Hunnic Period cemetery at Mukhino, in the Upper Don area", ArcheoSciences [Online], 33 | 2009, Online since 10 December 2012, connection on 01 February 2022. URL: http:// journals.openedition.org/archeosciences/2282 ; DOI: https://doi.org/10.4000/archeosciences.2282 


\title{
Gold foil covering of the handle of an iron knife from burial 2 of the Hunnic Period cemetery at Mukhino, in the Upper Don area
}

\author{
L'ornement en or du manche d'un poignard en fer de la tombe 2 \\ de la période des Huns de la nécropole de Moukhino, dans le Haut Don
}

\author{
Irina Saprykina*, Yurit A. Teterin** and Robert Mitoyan***
}

\begin{abstract}
The chemical composition of 7 fragments of the gold foil covering the wooden (?) handle attached to an iron knife from the burial of a noblewoman in the Upper Don area was investigated by two methods - XRF and X-ray electronic spectroscopy (XRS). All samples showed that the gold foil was produced from an Au-Ag-Cu alloy (type III), with a high degree of Ag concentration in the XRS samples. The data suggests that this is the result of the process of silver diffusion to the surface of the samples, but the reasons for this are not clear yet. The actual quality of the knife handle is low and, in comparison with other high-status objects, it cannot be included in the category of high-quality artefacts. Thus, we cannot exclude the possibility that the knife from burial 2 at Mukhino is a local copy, or an item produced in the 'metropolis' especially for export to the 'barbarian' world.

Résumé : Les compositions chimiques de 7 fragments de feuilles d'or couvrant le manche en bois (?) d'un couteau en fer provenant de la tombe d'une femme noble, trouvée dans le Haut Don, ont été déterminées par deux méthodes - FX et spectroscopie de diffusions de rayons X (XRS). Tous les échantillons montrent que les feuilles d'or ont été produites à partir d'un alliage Au-Ag-Cu (type III), avec une forte teneur en Ag dans le cas des échantillons analysés par XRS. Ces données suggèrent qu'il s'agit du résultat d'un procédé de diffusion d'argent vers la surface des échantillons, mais le mécanisme n'a pas encore pu être clairement défini. Le manche du couteau est de mauvaise qualité et, en comparaison avec d'autres objets de prestige, ne peut pas être inclus dans le groupe d'objets de bonne qualité. Pour cette raison, il ne peut pas être exclu que le couteau de la tombe 2 de la nécropole de Mukhino soit une copie de fabrication locale ou un objet produit dans la "métropole " spécifiquement pour exportation vers le monde "barbare".
\end{abstract}

Keywords: Burial of a noblewoman, gold foil covering of a knife handle, XRF analysis, X-ray electronic spectroscopy.

Mots-clés : Tombe noble, feuille d'or, manche de couteau, XRF, XRS.

\section{INTRODUCTION}

In 2002, a rich burial of a woman (burial 2) was discovered at the settlement of Mukhino, in the Upper Don region. So far, this is the only high-status burial in the Upper Don area (Southern Russia) dating to the Hunnic period.
Judging by the grave goods, the burial dates to the second quarter of the $5^{\text {th }}$ century $\mathrm{AD}$, that is, to the end of period D2 (Untersiebenbrunn horizon: 380/400-440/450 AD), or to the beginning of period D2/D3 (Smolin-Kosino horizon: 430/440-460/480 AD) on the chronological scale of the European Barbaricum. Such graves mark certain power

${ }^{*}$ RAS Institute of Archaeology - 117036, Dm.Ulyanova str., 19, Moscow, Russia. (dolmen200@mail.ru)

** The Kurchatov Institute - 123182, Kurchatov sq., 1, Moscow, Russia. (antonxray@yandex.ru)

*** Geological Faculty of the MSU, Chair of Geochemistry - 119992, Leninsky Gory, 1, Moscow, Russia. (mitoyan@geol.msu.ru) 

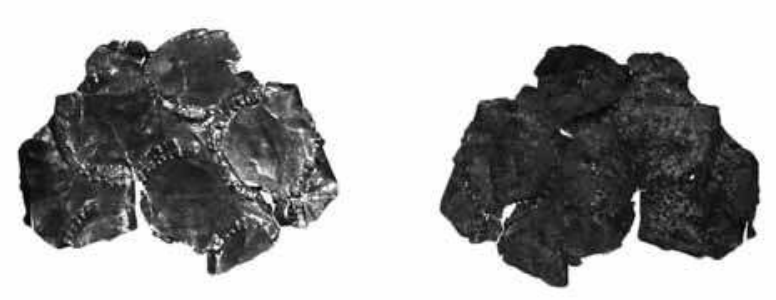

$1 \mathrm{~mm}$

Figure 1: (See colour plate) Fragment of gold foil covering. Figure 1: (Voir planche couleur) Fragment de feuille de couverture.

centres in the ancient pre-state formations of the East European 'barbarians' and also demonstrate that, geographical distances notwithstanding, the barbarian societies had a common hierarchical system.

The rich grave goods from burial 2 at Mukhino cemetery are compatible with the well-known 'princely' finds from sites in Central and Western Europe, such as for example Untersiebenbrunn or Airan. Together with other finds from Eastern Europe, the materials from Mukhino represent a reliable basis for creating a unified chronological scale for East European antiquities of the Great Migration period. The materials can also be useful for the study of social differentiation, as revealed by the quality and quantity of the grave goods.

Burial 2 yielded over 30 gold fragments, including the covering of the handle of an iron knife, made of a thin metal plate (foil) of golden colour, with a characteristic ornament not encountered on any of the other artefacts from the burial.

The iron knife with gold foil covering on the handle was found inside one of the samples of wood selected for radiocarbon analysis. The type of wooden item inside which the knife was found could not be identified with certainty, yet the part which is still extant and contained the knife could be interpreted as a sheath or scabbard.

The gold covering is fragmentary; yet, the overall amount of fragments and their location on the handle allow achieving a reliable reconstruction of the artefact.

Fourteen fragments of the gold foil are extant, all of them representing a thin and flexible plate with a maximum thickness of $0.5 \mathrm{~mm}$. The face is golden in colour and shows dark, almost black, spots. The reverse is dark and shows traces of some organic bonding agent. The foil must have been glued to the wooden handle with animal glue, since no traces of the chemical elements that indicate gilding have been found. The ornament was applied with a
Faulenzerpunzen tool, which had a defect of the working surface. All fragments of the gold foil showed the same defect, which indicates that all the fragments belong to one and the same object.

The other artefacts from burial 2 (plaques, mounts of plated metal) showed no analogies to the technique used for creating the knife handle covering. Nonetheless, similar coverings of sword handles and, less frequently, knife handles, are encountered in East European (Poland, Hungary) and North Caucasian cemeteries, and are characteristic of the Hun and post-Hun times. The metallurgy of gold-based alloys has been the subject of several studies (McDonald and Sistare, 1978; Rapson, 1990; Pinasco and Stagno, 1979).

The main focus of our work was to study the chemical composition of the gold foil covering from burial 2 at the Mukhino 2 cemetery and to compare it with the available data on other similar items.

\section{Methods}

XRF was used to analyze the chemical composition of the metal ( 7 fragments of the gold foil have been analyzed).

The analysis was carried out in the spectroscopy Laboratory of the Geological Faculty of Moscow State University (MSU) with a portable XRF analyzer: a laptop with special software, multichannel analyzer and sensor with radioisotope source (Am 241 and $\mathrm{Cd}^{109}$ isotopes) (developed by R. Mitoyan, S. Koloskov, N. Eniosova, T. Saracheva). The measurement procedure is standardized, and the methodology of the experiment is provided in the study by N. Eniosova, R. Mitoyan and T. Saracheva (2008: 114-120). The resulting data is presented in Table 1.

In order to obtain additional data regarding the gold and silver concentrations on the surface of the samples, their chemical composition was analyzed by X-ray electronic spectroscopy (XRS). The analysis was carried out in the precision spectroscopy laboratory of the Kurchatov Institute.

The samples were foil fastened to an aluminum support plate. The X-ray spectrum of the investigated samples $(191,192,195,200,205,207,208)$ were obtained using a MK II VG Scientific spectrometer with $\mathrm{AlK}_{\alpha} \mathrm{X}$-ray in vacuum $1.3 \cdot 10^{-7} \mathrm{~Pa}$ at room temperature. The methodology of the experiment is provided in the study by A. Yu. Teterin, M.V. Ryzhkov et al. (2006). The surface of the samples was strongly contaminated. 


\begin{tabular}{|c|c|c|c|c|c|c|c|}
\hline \multirow{2}{*}{ Reference } & \multicolumn{3}{|c|}{ XRS $=(-5 \mathrm{~nm}$ (surface) } & \multicolumn{3}{c|}{ XRF $(>0.5 \mathrm{~nm})$ (body) } \\
\cline { 2 - 8 } & $\mathrm{Au} \%$ & $\mathrm{Ag} \%$ & $\mathrm{Cu} \%$ & $\mathrm{~S} \%$ & $\mathrm{Au} \%$ & $\mathrm{Ag} \%$ & $\mathrm{Cu} \%$ \\
\hline 191 & 15.15 & 63.64 & - & 21.21 & 77.74 & 19.59 & 2.67 \\
\hline 192 & 16.67 & 55.00 & - & 28.33 & 84.23 & 14.22 & 1.55 \\
\hline 195 & 15.63 & 51.56 & 3.12 & 29.69 & 65.75 & 31.95 & 2.3 \\
\hline 200 & 5.99 & 65.27 & - & 28.74 & 69.36 & 29.15 & 1.49 \\
\hline 205 & 2.20 & 61.90 & 3.08 & 32.82 & 68.57 & 30.11 & 1.32 \\
\hline 207 & 1.98 & 70.30 & - & 27.72 & 65.02 & 33.31 & 1.67 \\
\hline 208 & 12.66 & 55.70 & - & 31.64 & 62.13 & 35.9 & 1.97 \\
\hline
\end{tabular}

Table 1: XRF and XRS data for the investigated samples (data from analysis of the samples without prior treatment of the surface; concentrations are given in atomic \%). Tableau 1 : Données par FX et XRS pour les échantillons analysés (correspondant à l'analyse des échantillons sans traitement au préalable de la surface, les concentrations sont présentées en \%).

\section{RESULTS AND DISCUSSIONS}

A comparison of the data obtained with the two methods shows significant differences in the main concentrations of the metal (Table 1).

Thus, the chemical analysis of the metal showed a variation in $\mathrm{Au}$ and $\mathrm{Ag}$ content: the surface of the foil contains $\mathrm{Au}$ in the range of $1.98-16.67 \%, \mathrm{Ag} 51.56-70.30 \%$; the body of the sample shows other results: Au 62.13-84.23\%, Ag 14.22-35.9\%. The copper content also shows variations. No other elements have been discovered (sulphur excluded).

Since the method of analysis is so well-developed that we can exclude the possibility of faulty methodology, other possible explanations for these results should be considered.

The data suggests that the silver diffused to the surface of the samples. This assumption is supported by the different $\mathrm{Au}$ and $\mathrm{Ag}$ concentrations on the surface and in the body of the samples. We assume that the initial $\mathrm{Au}$ and $\mathrm{Ag}$ content in the samples represented a medium value of the 'extreme points' presented in Table 1. Thus, the samples could have initially contained $\mathrm{Au}$ and $\mathrm{Ag}$ in equal proportions.

It is not clear why this particular type of gold alloy (type III, after Rapson 1990: 127-128) was used for the gold foil covering, since it is especially difficult to shape by pressure. As we recall, the knife originates from a rich burial of a woman who had a high social status (insofar as it can be confirmed by the results of analyzing other burials at Mukhino cemetery). On the colour scale, the alloy falls within the category of bleach alloys (Cretu and van der Lingen 1999), which are low-carat according to the modern classification (under 14 carat).

Our assumption is the following: during the Hunnic period, such gold-handled knives were status objects, certain power insignia, as far as the territory in question is concerned. Findings of such knives in the Upper Don area are extremely rare. Nonetheless, the actual quality of the knife handle is low, and, in comparison with other status objects, it cannot be included in the class of high-quality artefacts.
Thus, we cannot exclude the possibility that the knife from burial 2 at Mukhino is a local copy or an item produced in the 'metropolis' especially for export to the 'barbarian' world.

Further research on the subject will probably involve isotope analysis, which should clarify the origin of the metal.

\section{Acknowledgements}

This research was produced with the support of RSHF grant 08-01-00013a.

\section{References}

Cretu, C. and van der Lingen, E., 1999. Coloured gold alloys. Gold Bulletin 32(4): 115-126.

McDonald, A.S. and Sistare, G.H., 1978. The metallurgy of some carat gold jewellery alloys. Gold Bulletin 11(3-4): 66-73.

Pinasco, M.R. and STAgno, E., 1978. Deformation and recrystallization of a jewellery white gold alloy. Gold Bulletin 12(2): 53-57.

Rapson, W.S., 1990. The metallurgy of the coloured carat gold alloy. Gold Bulletin 23(4): 125-134.

Teterin, Yu.A., Ryzhkov, M.V., Maslakov, K.I., Vukcevic, L. and Panov, A.D., 2006. Electronic structure of solid uranium tetrafluoride UF4. Physical Review B 74(4): 045101 (1-9).

Eniosova, N., Mitoyan, R. and Saracheva, N., 2008. Methods for the study of nonferrous chemical compounds, in Nonferrous and precious metals and alloys in Medieval Eastern Europe. Moscow, (in Russian).

ArcheoSciences, revue d'archéométrie, 33, 2009, p. 255-257 
